\title{
Eutrophication of Lake Reghaïa
}

\author{
Togola Astan Aljaouja ${ }^{1}$, Ling Liu ${ }^{2}$ \\ 12 College of Hydrology and Water Resource, Hohai University, 210098, Nanjing, China
}

\begin{abstract}
This work describes the study of eutrophication in Lake Reghaia, located $30 \mathrm{~km}$ to the east of Algiers and $2 \mathrm{~km}$ from the town of Reghaïa. Eutrophication is a but natural pollution of some aquatic ecosystems form that occurs when the environment receives too much nutritious substances for algae and they proliferate in outstanding amount, degrading the entire ecosystem. Key nutrients at the origin of this phenomenon are phosphorus. Eutrophication is a growing threat to Lake Reghaïa. It induces a significant deterioration in water quality which can lead to economic losses and risks to human health. The study of improved Vollenveider model confirms that Lake Reghaïa is significantly polluted by human activities and the phosphorus load is estimated. Keywords: Eutrophication, Lake Reghä̈a, Modelling, Phosphorus, Pollution.
\end{abstract}

\section{Introduction}

After more than a century of being ruled by France, Algerians fought through much of the 1950s to achieve independence in 1962. Algeria's primary political party, the National Liberation Front (FLN), was established in 1954 as part of the struggle for independence and has largely dominated politics since.

State of North Africa, Algeria, bathed in the north by the Mediterranean Sea, is limited to the west by Morocco and Western Sahara, to the South by Mauritania and Mali, Southeast by Niger and to the east by Tunisia and Libya. With an area of $2381741 \mathrm{~km}^{2}$, it is both the largest country of Africa, the Arab world and the Mediterranean basin. Its capital Algiers, is in the north of the country, on the Mediterranean coast.

The north of the country has a Mediterranean climate; summers are hot and dry and winters are mild and rainy and sometimes snowy. This area is the wettest of Algeria, it is characterized by annual rainfall ranging between 400 and $1000 \mathrm{~mm}$ of water. Kabylia has a relatively abundant rainfall which facilitated the development of a typical agriculture. In Kabylia, the inland areas are wetter because of the ascent and decompression of the humid winds: thus, Larbaâ Nath Irathen, rainfall is $1059 \mathrm{~mm}$ against $833 \mathrm{~mm}$ in Tizi Ouzou.

In north western Algeria during the summer months, rainfall becomes scarce or nonexistent, and the sky is bright and clear. The subtropical anticyclone covers the Oran region for nearly four months. However, the region is well watered during the winter. The low rainfall (294 mm rainfall and frequency 72 to 9 days per year) are also characteristic of this climate.

Sahara regions are characterized by an arid and dry climate. In the north, the rainfall reaches $100 \mathrm{~mm}$ of annual average while in the south, it is $20 \mathrm{~mm}$. In coastal areas, the annual average is $200 \mathrm{~mm}$. However, heavy rains are recorded in Algeria in several cities. The damage is considerable. In 2008, the city of Ghardaia, part of World Heritage, was flooded by a large amount of torrential rain. The annual rainfall in the highlands and in the Saharan Atlas do not exceed the amount 200 to $400 \mathrm{~mm}$ of rain. But the height of the annual rainfall is often less than $130 \mathrm{~mm}$ across the Algerian Sahara.

The rainfall is erratic, with sometimes pronounced droughts. Algeria is one of the countries where water availability is limited while needs are growing (Meriem, 2014). The lake of Reghaiia is a coastal lagoon of 75 ha, which represents the last wetland of the Great Plains of the Mitidja. Indeed, its proximity to the capital and its diverse ecosystem, gives it, despite its small size, great importance in terms of impact on urban populations and a didactic demonstration of multiple values of wetlands. Several ecosystems are represented (Sea, islands, beach, lake and wetlands). It is the single site of water for birds in the Mitidja; there have been more than 230 species of birds of which three are rare worldwide: Marbled Teal, The White-headed Duck, The Ferruginous Duck.

The wet area is influenced by the impact of the industrial activities in the cities of Reghaïa and Rouiba (tanneries, printing, detergents etc...) and discharge of wastewater, agricultural activity is also very important and characterized by excessive pumping of water and the unsuitable use of pesticides for agricultural practices (Benabdi, 2015).

All this explains why its water is polluted due to domestic waste, industrial and agricultural, which limits its self-purification power caused by toxic substances, and accelerates its pollution. Eutrophication is defined in the usual sense as the natural or artificial wastewater nutrient enrichment, almost mainly phosphorus and nitrogen. Other nutrients, hydrological and other factors such as climatic conditions (light, temperature) (volume and degree of containment of the bodies of water etc.) control the eutrophication process. 
Eutrophication, due to high load of nitrogen and phosphorus is the main environmental problem of lakes and rivers in the world for decades. Efforts are being made in many countries to decrease the rate of nitrogen and phosphorus through the external wastewater treatment or diversion of the stream rich in nitrogen and phosphorus (Erik \& al, 2012).

\section{Study area description}

\section{Methods And Material}

So, the term "REGION AGHA YAHIA" which was reduced to RE GHA IA is transformed into a single word "Reghaïa" by settlers since before 1830 , there is no document that cites the term Reghaïa through the archives. Our study focuses on the Reghaïa lake located $30 \mathrm{~km}$ east of the center of Algiers and $14 \mathrm{~km}$ from the town of Boumerdes. Its geographical coordinates are longitude $3^{\circ} 19^{\prime}$ and $3^{\circ} 21^{\prime}$ east and latitude $36^{\circ} 45^{\prime}$ and $36^{\circ} 48^{\prime}$ north. The perimeter of Reghaïa is bordered to the north by the Mediterranean Sea, to the south by the national road linking Algiers to Constantine, to the east by the town of Boudouaou and west by the town of Ain Taya. There is a lake and marshes, surrounded by a wooded belt and a sandy coast that opens onto a small exceptional seabed behind. The lake is located 4 meters above sea level, its depth varies from a few centimeters to 6 meters. Immediate banks are gently sloped zero times (0 to 3\%). The altitude rises in places to $35 \mathrm{~m}$ in the hills. The slopes of the lake are relatively mild and its elongation is North South. The marquis occupies the steep slopes (12.5\% to $25 \%$ ). Topography, complex enough, is represented by four varied configuration trays: Plateau West Bordj El Bahri and Ain Taya, the Plateau is Boudouaou, South Plateau encompassing all lands from up Hamiz city Reghaïa and Plateau-Central region which covers the entire area crossed by Oued Reghaïa.

In the northern part of the valley extend fixed dunes that separate the lake from the sea. The ReghaïaHeuraoua area is the northernmost part of the agricultural plain of Mitidja; this is where the plain comes into direct contact with the Mediterranean. It is a territory where agricultural vocations are dominant and where the rustic tables strongly impress the landscape. But it is also an area including the town of Reghaïa, where industrial activities are important nationwide. This industrial development direction will inevitably lead to a very dense urbanization, to the detriment, of course, agricultural and natural areas, which have experienced a great decline, especially for thirty years. The direct impacts of industrial and urban development are reducing the natural environment and, consequently, the plant and animal diversity and an almost total disappearance of rare genetic resources as is the case, for example, cork oaks forest Kerrouch at Reghaïa on Pliocene sands, particularly ecotype that is not found much farther west, in the Oran region (forest M'sila) and Morocco (forest of Mamora).

The French administration has made in 1930 to build a dam giving a detention. The dam was built slightly at the upstream of the river from the mouth of the river Reghaïa. The main objective of this development was the irrigation of fertile farmland in the south, east and west of the swamp.

Between 1970 and 1974, the desilting works were committed and the realization of a canal on the northern part of the lake, overlooking the Mediterranean Sea. In 1983, the forest sector created by decree on hunting Centre Reghaïa to produce birds for restocking of wetlands and dams (especially ducks). In 1997, a sewage treatment plant located at the upstream of the lake was created. This station provides only the mechanical treatment of domestic and industrial wastewater treatment scheduled for 8 million cubic meters in the finals. In 2003, the wetland marshes Reghaïa was on the list of the Ramsar Convention on Wetlands of International Importance (Hamdan, 2012). The area of Reghaïa is an agricultural area where we found mainly market gardening and citrus cultivation, which occupy a large area.

This site, called "Reserve of Lake Reghaïa", is now the only sanctuary where nature has found refuge in the whole area, it will be the main element of this phase relationship. Pollution of the lake is attested both by the rarity of the flora and aquatic fauna by the results of physic-chemical quality analysis; waters reaching them are not pure in their entirety and the treatment plant provides only primary treatment of domestic wastewater.

The water quality of Reghaïa lake was based on the analysis of the campaign on water at the entrance, exit and in the lake. The wastewater is functional since 1997, receives and processes of water daily to the industrial park and the cities. The only work in progress in the treatment plant consist of cleaning, purging and oil removal. The processing work before the release of water is clearly insufficient to be able to get clean water before discharging into the lake. 


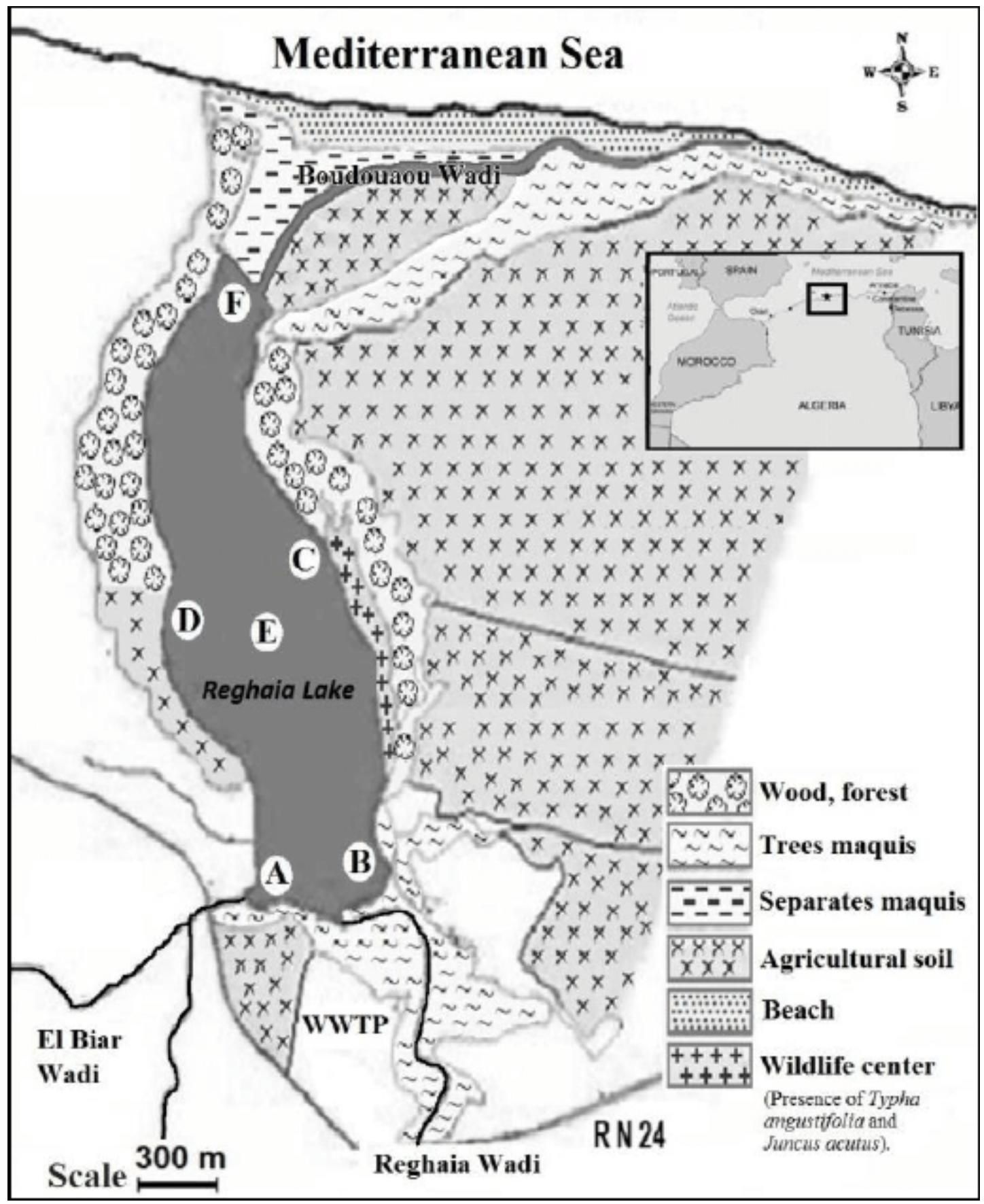

Map: Location of the study area.

\section{Data acquisition and methodology}

To face the problem of eutrophication in Reghaia's Lake, the assessment of the quality of the water is needed. A study the physicochemical, and chemical of waters, were carried out. From 2004 to 2007, monthly assessment was made specifically at the upstream of the river, the middle and the downstream of the river. Oxygen dissolved were analyzed by the chemical method of Winkler. The chemical variables were analyzed by colorimetric methods using a spectrophotometer. The different analyses were performed in the laboratory of ANRH (National Agency for Water Resources), in Algeria. The results constitute the fundamental data base of this study. 


\section{$>$ Phosphorus}

\section{Results And Discussion}

It is a constituent of plant tissue; it limits plant growth; it represents what is called a "limiting factor". Phosphorus is widely distributed in nature, never in the free state, but generally in the form of orthophosphate and total phosphate. Phosphorus is an essential element for plant life, but when there is too much of it in water, it can speed up eutrophication (a reduction in dissolved oxygen in water bodies caused by an increase of mineral and organic nutrients) of rivers and lakes. However, can lead to greater growth and more biomass of algae and plants, which when they die, result in a higher oxygen consumption during the degradation of the organic matter. This is what causes low oxygen near the sediments (Haiming, 2016).

\section{Classification of Trophic States}

Trophic levels used to classify lakes per their degree of biological productivity, their conditions can vary from very oligotrophic to highly eutrophic. The evolution of a lake is not done abruptly. Rather, it is a process of aging which is gradual and changes occur as eutrophication. The determination of the trophic level of a lake is to position this lake on the trophic level. The classification is carried out by using reference values (see the table below) for phosphorus concentration, "chlorophyll a" concentration and the transparency of the water (Mddelcc, 2016).

Table 1: Classification of the trophic level of lakes (Mddelcc, 2016).

\begin{tabular}{|c|c|c|c|c|}
\hline \multicolumn{2}{|c|}{ Trophic classes } & \multirow{2}{*}{$\begin{array}{c}\begin{array}{c}\text { Total phosphorus } \\
(\boldsymbol{\mu g} / \mathbf{l})\end{array} \\
\text { Average }\end{array}$} & \multirow{2}{*}{$\begin{array}{c}\begin{array}{c}\text { Chlorophyll a } \\
(\boldsymbol{\mu g} / \mathbf{l})\end{array} \\
\text { Average }\end{array}$} & \multirow{2}{*}{$\begin{array}{c}\text { Transparency (m) } \\
\text { Average }\end{array}$} \\
\hline Main class & secondary class (transition) & & & \\
\hline Ultra-oligotrophic & & $<4$ & $<1$ & $>12$ \\
\hline \multirow[t]{2}{*}{ Oligotrophic } & & $4-10$ & $1-3$ & $12-5$ \\
\hline & Oligo-mesotrophic & $7-13$ & $2.5-3.5$ & $6-4$ \\
\hline \multirow[t]{2}{*}{ Mesotrophic } & & $10-30$ & $3-8$ & $5-2.5$ \\
\hline & Meso-eutrophic & $20-35$ & $6.5-10$ & $3-2$ \\
\hline Eutrophic & & $30-100$ & $8-25$ & $2.5-1$ \\
\hline Hypereutrophic & & $>100$ & $>25$ & $<1$ \\
\hline
\end{tabular}

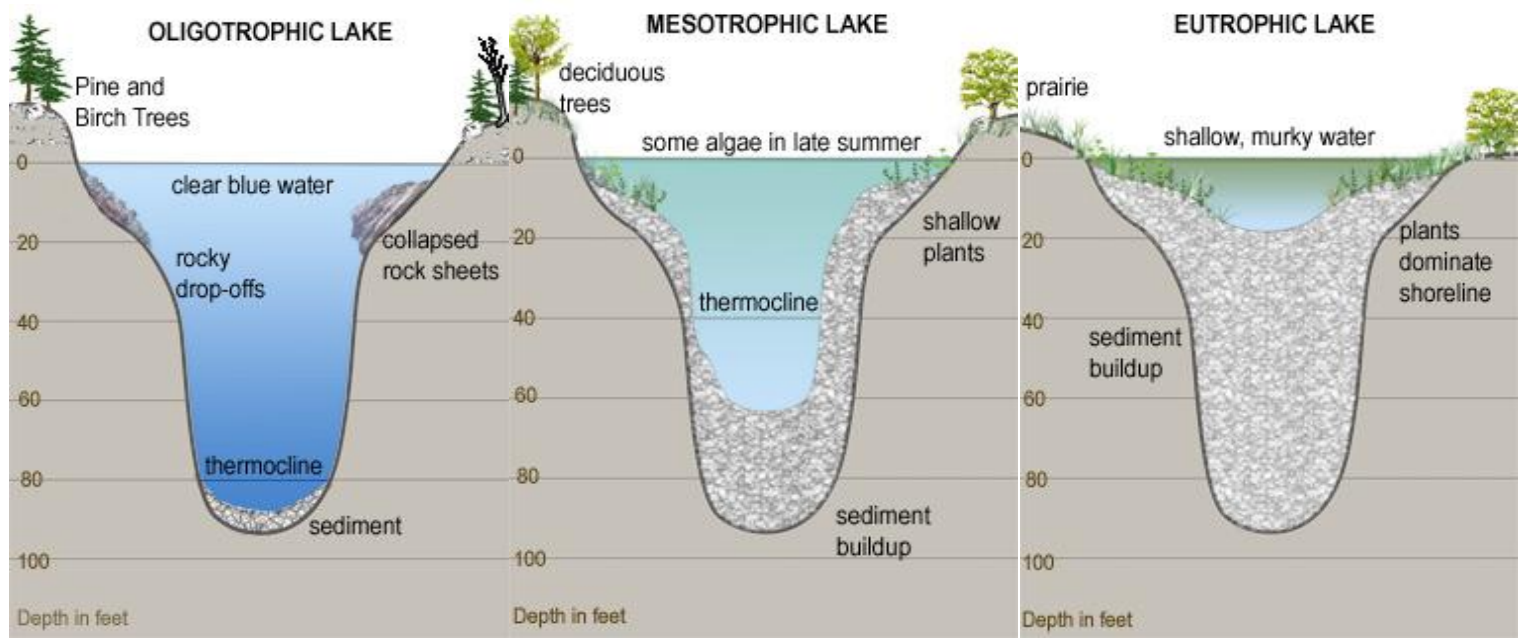



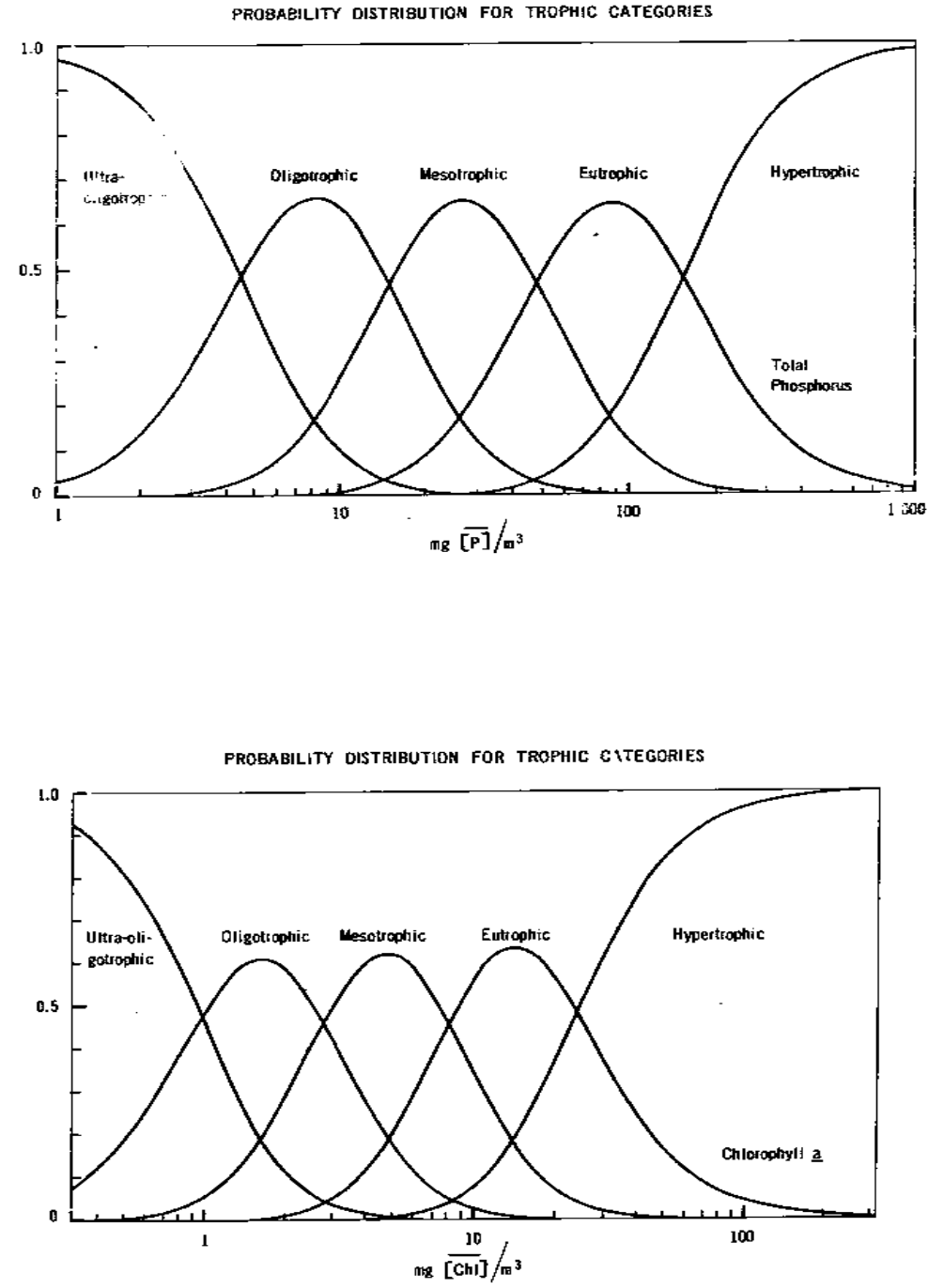

Figure 1: OECD Trophic State Classifiction Probabilities

\section{Modelling of Vollenweider's Phosphorus Inputs}

There are a number of simple models to treat phosphorus inputs and concentrations, for example: Vollenweider 1976 Richard (2014); Vollenweider 1982 Kelly \& al (2014) which are established from regressions on a large number of bodies of water to estimate the trophic level of a reservoir from the annual phosphorus load. These different models remain empirical and the results they may give are related to the types of deductions on which these formulations have been adjusted.

We have adopted the model of Vollenweider, binding input in phosphorus load and response of the waterbody, defined by the simple equation:

$P T=\left(\frac{L p}{q S}\right) *(1+\sqrt{T S})$

Where:

$\mathrm{PT}=$ annual average total phosphorus in water $(\mathrm{mg} / \mathrm{l})$;

$\mathrm{Lp}=$ annual contribution of phosphorus / unit area $\left(\mathrm{mg} / \mathrm{m}^{2} /\right.$ year $)$;

$\mathrm{qs}=$ annual intake of water/unit area $(\mathrm{m} / \mathrm{yr}) \rightarrow \mathrm{m}^{3} / \mathrm{m}^{2} \rightarrow \mathrm{m}$;

$\mathrm{TS}=$ residence time of water (year).

Data Used:

The data used for this model are based on the analysis during the years 2004 to 2007 by the ANRH services

They relate to:

-Liquid inputs;

-Intakes of phosphorus;

-The residence time of the water. 
Table 2: Annual total inputs in phosphorus and annual liquid inputs of Reghaïa of 2004 lake.

\section{Source: ANRH}

\begin{tabular}{|c|c|c|c|c|c|}
\hline $\mathbf{2 0 0 4}$ & Upstream & Depth 0.5m & $\begin{array}{c}\text { Depth } \\
\mathbf{3 m}\end{array}$ & $\begin{array}{c}\text { Depth } \\
\mathbf{6 ~ m}\end{array}$ & Downstream \\
\hline L: Total annual phosphorus inflow $(\mathrm{mg})$ & 3.441010 & 3.811010 & - & 3.591010 & 3.441010 \\
\hline Load $(\mathrm{Lp})(\mathrm{mg} / \mathrm{h})$ & 2.87104 & 3.18104 & - & 2.99104 & 2.87104 \\
\hline$[\mathrm{p}]_{\mathrm{j}}(\mu \mathrm{g} / \mathrm{l})$ & 460.82 & 510.60 & - & 480.09 & 460.82 \\
\hline $\mathrm{qs}(\mathrm{m} / \mathrm{yr})$ & \multicolumn{5}{|c|}{62.28} \\
\hline TS $($ year) & \multicolumn{5}{|l}{1.00} \\
\hline Annual liquid inflow to the Lake $\left(\mathrm{hm}^{3}\right)$ & \multicolumn{5}{|l}{} \\
\hline
\end{tabular}

Table 3: Annual total inputs in phosphorus and annual liquid inputs of Reghaïa of 2005 lake.

\begin{tabular}{|c|c|c|c|c|c|}
\hline 2005 & Upstream & $\begin{array}{c}\text { Depth } \\
\text { 0.5m }\end{array}$ & Depth 3m & $\begin{array}{c}\text { Depth } \\
\text { 6m }\end{array}$ & Downstream \\
\hline L: Total annual phosphorus inflow (mg) & 3.021011 & 3.08 .1011 & - & 3.131011 & 3.191011 \\
\hline Load (Lp) (mg/h) & 2.52105 & 2.57105 & - & 2.61105 & 2.66105 \\
\hline$[\mathrm{p}]_{\mathrm{i}}(\mu \mathrm{g} / \mathrm{l})$ & 53066 & 541.19 & - & 549.61 & 560.14 \\
\hline $\mathrm{qs}(\mathrm{m} / \mathrm{yr})$ & \multicolumn{5}{|c|}{474.88} \\
\hline Annual liquid inflow to the Lake $\left(\mathrm{hm}^{3}\right)$ & \multicolumn{5}{|c|}{569.86} \\
\hline TS (year) & \multicolumn{5}{|c|}{1.00} \\
\hline
\end{tabular}

Source: ANRH

Table 4: Total annual inflow in phosphorus and annual liquid inputs of Reghaïa of 2006 lake.

\begin{tabular}{|c|c|c|c|c|c|}
\hline Year 2006 & Upstream & Depth 0.5m & $\begin{array}{c}\text { Depth } \\
\text { 3m }\end{array}$ & $\begin{array}{c}\text { Depth } \\
\text { 6m }\end{array}$ & Downstream \\
\hline $\begin{array}{c}\text { L: Total annual phosphorus inflow } \\
(\mathrm{mg})\end{array}$ & $4.4410^{10}$ & $4.8410^{10}$ & - & $5.1510^{10}$ & $4.9510^{10}$ \\
\hline $\begin{array}{c}\text { Load }(\mathrm{Lp})(\mathrm{mg} / \mathrm{h}) \\
{[\mathrm{p}]_{\mathrm{j}}(\mu \mathrm{g} / \mathrm{l})}\end{array}$ & $3.710^{4}$ & $4.0310^{4}$ & - & $4.2910^{4}$ & $4.1310^{4}$ \\
\hline $\mathrm{qs}(\mathrm{m} / \mathrm{yr})$ & 439.96 & 479.19 & - & 510.11 & 491.09 \\
\hline $\begin{array}{l}\text { Annual liquid inflow to the Lake } \\
\left(\mathrm{hm}^{3}\right)\end{array}$ & \multicolumn{3}{|l|}{100.92} \\
\hline \begin{tabular}{l} 
TS (year) \\
\hline
\end{tabular} \\
\hline
\end{tabular}

Source: ANRH

Table 5: Total annual inflow in phosphorus and annual liquid inputs of Reghaïa of 2007 lake.

\begin{tabular}{|c|c|c|c|c|c|}
\hline 2007 & Upstream & Depth $0.5 \mathrm{~m}$ & Depth 3m & $\begin{array}{c}\text { Depth } \\
6 \mathrm{~m}\end{array}$ & Downstream \\
\hline L: Total annual phosphorus inflow (mg) & - & 4.951010 & - & - & 4.681010 \\
\hline Load (Lp) (mg/h) & - & 4.13104 & - & - & 3.9104 \\
\hline$[\mathrm{p}]_{\mathrm{j}}(\mu \mathrm{g} / \mathrm{l})$ & - & 720.89 & - & - & 680.75 \\
\hline qs $(\mathrm{m} / \mathrm{yr})$ & \multicolumn{5}{|c|}{57.29} \\
\hline Annual liquid inflow to the Lake $\left(\mathrm{hm}^{3}\right)$ & \multicolumn{5}{|c|}{68.75} \\
\hline TS (year) & \multicolumn{5}{|c|}{1.00} \\
\hline
\end{tabular}

Source: ANRH

The results of equation (1) deducted from the data, tables $(2,3,4,5)$ are grouped in table 6 :

Tables 6: Results of the application of Vollenweider to data tables $(2,3,4,5)$

\begin{tabular}{|c|c|c|c|c|c|}
\hline \multirow{2}{*}{ Years } & \multicolumn{5}{|c|}{ Downstream } \\
\cline { 2 - 6 } & Upstream & Depth 0.5m & Depth 3m & Depth 6m & Dm \\
\hline 2004 & 921.64 & 1021.20 & - & 960.18 & 921.64 \\
\hline 2005 & 1061.32 & 1082.38 & - & 1099.22 & 1120.28 \\
\hline 2006 & 879.92 & 958.38 & - & 1020.22 & 982.18 \\
\hline 2007 & - & 1441.78 & - & - & 1361.50 \\
\hline
\end{tabular}

Source: author's calculation

The results of the annual concentration of total phosphorus in the lake of Reghaïa, determined per the simple relationship of Vollenweider 1976 (Richard, 2014), are higher. Per the values of the thresholds of the fixed system of classification of trophic status established by (Mddelcc, 2016) (table 6), Reghaïa lake is classified in the category of hyper-eutrophic water plans. This classification has been established for water bodies lying in temperate zones which initially present a greater risk of eutrophication. This relationship could not be applied to the Lake located in the Mediterranean area. We have tried to adapt the relationship enhanced by Vollenweider 1982 (Kelly \& al, 2014) in this case. 


\section{Improvement of the model of Vollenweider}

The empirical relationship - (equation 1) was perfected by Vollenweider 1982 (Kelly \& al, 2014) and given in the form:

$[\mathrm{P}]_{\mathrm{y}}=\mathrm{a}(\mathrm{x})^{\mathrm{b}}$

Where:

$[\mathrm{P}]_{\mathrm{y}}=$ annual average concentration total phosphorus in the lake $(\mu \mathrm{g} / \mathrm{l})$; $\mathrm{a}=1.55$ and $\mathrm{b}=0.82$

$$
\begin{gathered}
X=\frac{[P]_{j}}{(1+\sqrt{T S})} \\
{[P]_{j}=\frac{L p}{q S}}
\end{gathered}
$$

$[P]_{j}=$ average concentration phosphorus inputs in annual water $(\mu \mathrm{g} / \mathrm{l})$;

So, writing detailed this equation (2) is:

$[P]_{y}=1.55 *\left(\frac{[P]_{j}}{(1+\sqrt{T S})}\right)^{0.82}$

This equation has been obtained on a study on 180 Lakes and artificial reservoirs in temperate areas.

\section{Implementation of the Improved Equation on the lake of Reghä̈a}

The results of equation (3) for the same data tables $(2,3,4,5)$ are grouped in table (7)

Table 7: Results of the implementation of the Vollenweider 1982 (Kelly \& al, 2014) based on tables $(2,3,4,5)$

\begin{tabular}{|c|c|c|c|c|}
\hline \multirow{2}{*}{ Years } & \multicolumn{4}{|c|}{} \\
\cline { 2 - 5 } & Upstream & Depth 0.5 m & Depth 6m & Downstream \\
\hline 2004 & 134.15 & 145.92 & 138.73 & 134.15 \\
\hline 2005 & 150.61 & 153.05 & 155.00 & 157.43 \\
\hline 2006 & 129.15 & 138.52 & 145.80 & 141.33 \\
\hline 2007 & - & 193.62 & - & 184.73 \\
\hline
\end{tabular}

$$
[P]_{y}=1.55 *\left(\frac{[P]_{j}}{(1+\sqrt{T S})}\right)
$$

$[P]_{y}(\mu \mathrm{g} / \mathrm{l})$

Source: author's calculation

Equation (3) this calculates the annual average concentration of total phosphorus in the lake of Reghaïa, based on mean concentrations of phosphorus in annual water inflow and the residence time of water in the Lake, per the Vollenweider 1982 (Kelly \& al, 2014). Classification thresholds values adopted by the Mddelcc (2016), for the trophic system classify our lake in the category still hyper-eutrophic but with a decrease in values (table 7).

\section{Conclusion}

We monitored four years (2004-2007) data, the phenomenon of eutrophication by excess nutrient inputs of Reghaïa Lake. It has been noticed for Lake Reghaïa a significant decrease in oxygen at the hypolimnion. When they are abundant, the medium phosphorus becomes harmful and characterizes the phenomenon of eutrophication. We chose the Vollenweider model to make our analyses, preference which is explained by the simplicity of calculations and the small number of data needed. Vollenweider 1982 (Kelly \& al, 2014) provides a good example of development and utilization of phosphorus empirical model for estimating a wide range of lake eutrophication.

And after the threshold values of the fixed system of classification of the trophic state established by the Mddelcc (2016), the results of the concentration of phosphorus by the application of the model of Vollenweider in table 6, classified the waters of the lake of Reghaïa as hyper-eutrophic. Similarly, the concentrations in table 1 , the class is the hyper-eutrophic category. Despite the difference between the results 
obtained by the model improved by Vollenweider 1982 (Kelly \& al, 2014) in table 7 and those measured, our lake's waters remain classified as hypereutrophic. But this difference may have several origins:

- The model assumes that water is a homogeneous reactor, that there is no difference in concentration in the water column, and the water of output concentrations are equal to those in the waters of the waterbody. These assumptions are difficult to apply. They also assume constant phosphorus intakes over the study period and data do not verify this hypothesis.

- We were faced with a lack of homogeneity of the parameter data, mainly due to the difficulties inherent in the field measurements.

The lake of Reghaïa is intended for irrigation, the lake reserve is maintained to ensure a certain capacity for water until the first rains. It is therefore important to preserve the quality of its water and to fight against pollution.

\section{Acknowledgement}

The authors would like to thank the National Agency for Water Resources (ANRH) Algeria, for the provision of data.

\section{Reference}

[1]. Anrh. Agence nationale des nessources hydriques (National agency for water resources) Monthly Bulletins Quality of Superficial Waters Oran, Algeria

[2]. Benabdi M. \& Bachetarzi R. 2015 Bilan diagnostic de la réserve naturelle de Algérie (Bilan diagnostic nature reserve reghä̈a algeria in 2015), Car/asp - PNUE/PAM 2015 edn Car/asp - Projet MedMPAnet, Tunis, p. 55

[3]. Erik J., Martin S., Torben L. L., Thomas A. D., Zhengwen L., Nestor M., Carolina T., Korhan O., Henning S. J., Dennis T., Fernendo S., Xavier L., Liselotte S. J., Rikke B., Lone L., Soren E. L., Frank L., Sara E. \& Mariana M. 2012 Biomanipulation as a restoration tool to combat eutrophication: recent advances and future challenges. Advance in Ecological Research, 47, 411-488.

[4]. Haiming Z. \& Yan W. 2016 Phosphorus removal and recovery from domestic wastewater in a novel process of enhanced biological phosphorus removal coupled with crystallization. Bioresource Technology, 211, 87-92.

[5]. Hamdan M. 2012 Plan cotier de reghaïa: sites naturels et biodiversité terrestre état des lieux et diagnostic (Poastal plan reghaïa: natural and terrestrial biodiversity status and diagnosis in 2012), Strategic Partnership for the Mediterranean Large Marine Ecosystem

[6]. Kelly D. J., Robertson H. A. \& Allen C. 2014 Nutrient loading to canterbury high-country lakes for sustaining ecological values. Prepared for the Department of Conservation and Environment Canterbuty. Cawthron Report, 2557, 61.

[7]. Mddelcc. 2016 Ministère du développement durable de l'environnement et de la lute contre les changements climatiques (Ministry of sustainable development environment and the fight against climate change in 2015), The volunteer monitoring network of lakes, http://www.mddelcc.gouv.qc.ca/eau/rsvl/methodes.htm.

[8]. Meriem N. A. A. \& Ewa B. A. 2014 Algerie carrying capacity with respect to per capita domestic water use. Sustainable Cities and Society, 13, 1-11.

[9]. OECD: Organisation for Economic Co-operation and Development. Colorado Water Resources Researrch Institude. Completion Report, 195.

[10]. Richard N. 2014 Lake singletary trophic status model and management plan. Lake Singletary Watershed Association 